\title{
Prostate Cancer cT2a TNM Finding v7
}

National Cancer Institute

\section{Source}

National Cancer Institute. Prostate Cancer CT 2a TNM Finding v7. NCI Thesaurus. Code C89215.

Prostate cancer with tumor involving one-half of one lobe or less. (from AJCC 7th Ed.) 